\title{
Community Legal Compliance with the Certification of Proprietary Rights Over Land in Takalar Regency, South Sulawesi, Indonesia
}

\author{
Dr. Muhammad Rustan, S.H.,M.Hum \\ Lecturer of Kopertis Region IX, the dpk of the UPRI Makassar-Indonesia
}

\begin{abstract}
This study aims to analyze the level of community legal compliance, and analyze the social and economic factors that influence the certificate of land property rights. This research used a method of sociojuridical. The population is about 2,250 people, and sampling of 75 respondents. Types of data, qualitative and are quantitative, primary and secondary data sources, data analysis frequency tables and chi-square. The results showed the level of community legal compliance with the certification of land property rights are still relatively moderate, because the certificate of the ownership rights over land increased after a subsidy from the World Bank. Socioeconomic factors are still considered a weak influence on the certificate of land ownership is due to the certification costs less affordable by the community.
\end{abstract}

Keywords: Legal compliance, certification of property rights over land, and socio- economic

\section{Background}

\section{INTRODUCTION}

In essence, all the land in the entire territory of the Republic of Indonesia is a gift of God Almighty to the people of Indonesia who have been united into a nation of Indonesia (Article 1 of the Basic Agrarian Law). The Article stipulates that the land contains religious communalist conception, which underlies the national land law in Indonesia. Even communalist, but did not have possession and use collectively continuously. In the conception of the possible is existence of individual mastery of the form of property rights of the land. There may be rights to land for the purposes of land that must be met by every human being. Therefore, the authority is given to man not only to master and possess it, but uses the land itself.

Possible individuals and entities controlled most of the land, is the real purpose for their land will be met. Then the issuance of land property rights to him not only gives authority to master, but once the obligation to use it (the principle of beneficence). According Boedi Harsono ${ }^{1}$ that on the basis of the controlling right of this state later in the BAL as referred to in Article 4 joncto Article 16 has been mentioned several kinds of rights to land that can be provided to and owned by others is the right property, the right to cultivate, building rights, use rights, lease rights, and others.

Since the enactment of the Basic Agrarian Law (BAL) in Indonesia in 1960 for the land owners have to register their land in the Land Office to obtain a certificate of land ownership rights. Because the rules of the rights of the land prior to the enactment of the BAL still pluralistic or dualism land law which caused a lot of land that has not been registered with the Land Office until now.

In the explanation of the Government Regulation No. 24 of 1997 confirmed that about 55 million lands right eligible for registration, the new registered approximately 16.3 million $^{2}$. Basriduring $\operatorname{Hasan}^{3}$ stated that the development of the reform is so far in the land management has not provided a sense of security in society, both in obtaining legal protection and in the acquisition of rights.

Therefore, the management of the land during the reform has not also give a sense of security to the citizens in terms of land laws in this case due to the land certificate has not been done thoroughly in the community and there are still many cases of land overlapping of their rights due to double the certificate that sometimes appears on the community.

According to Susilo Bamban Yudhoyono ${ }^{[4]}$ as President VI is claimed that during the period 2005 to 2008 have been redistributed land area of 349.519 hectares, while during the time frame 1961 to 2004 was only

\footnotetext{
${ }^{1}$ Boedi Haarsono, 2008, History Formation Basic Agrarian Law Contents and Implementation, Jambatan Jakarta.

${ }^{2}$ Yudha Pandu, 2010, Legislation Association's Rights to Land, Indonesia Legal Center Publishing, page 276

${ }^{3}$ Ibid, 2008, page 457

${ }^{4}$ Google, www//http//wwn Surakarta, Adimin 8 January 2008 
54,500 hectares of land. The National Land Agency stated that there are 85 million new pieces of land in Indonesia around $30 \%$ were registered and given land rights, and even then not those perfect also because many overlapping land ownership.

Jose Alice Diemel ${ }^{5}$ that in Bolovia country after the agrarian reform in 1996-2006 about 7.6 million hectares or 68 percent of the land holdings are small, communal and indigenous peoples who are certificated by the government of Bolovia of the total land of 11.4 million hectares. These figures show the certificate of land in Bolovia higher than in Indonesia.

In many cases of land in Indonesia is not yet registered in the Land Office or not certification, the fruit of the mind in order to seek a strategic format or program to improve law compliance for the business community on land titling property rights that need to be traced as early as possible.

\section{Statement of Problems}

1. What is the level of community legal compliance with the certification of land ownership rights in Takalar Regency?

2. What is the factors influence the level of economic society certificate of land property rights in Takalar Regency?

\section{THEORETICAL BACKGROUND}

\section{Definition of Land Certification}

To certify land, property rights are the duty of the Land Office Regency/City. The certification of land ownership rights is the end product of land registration activities. These activities there were held regular (conventional) and in bulk as bulk certification (BC).

In Article 1, paragraph 20 of Government Regulation No. 24 of 1997 affirms that the certification is proof of the rights which contains data on juridical and physical data objects that are listed to the right to land, property rights, land ownership of the apartment units and mortgages respectively recorded in the land book.

According Boedi Harsono ${ }^{6}$ that land registration is a series of activities undertaken by the state/ government continually and regularly. It was collecting information or specific data regarding certain lands exist in certain areas, processing, storage, and presentation for the benefit of the people in order to provide assurance, legal certainty in the area of land, including the issuance of receipts and maintenance.

Said a "series of activities" showed a variety of activities in the implementation of land registration, which related to one another sequentially into a single circuit that leads to the unavailability of data required in order to guarantee legal certainty in the field of land to the people. While the word continually demonstrates to the implementation of activities that begins will have no end. The data has been collected and is available to be adapted to the changes that occur later, so keep in accordance with the circumstances that later.

Effendi Perangin ${ }^{[7]}$ stated that the certificate of land ownership rights is proof of land rights/ encumbrance issued by the competent authority in the context of land registration.

Therefore, for the issuance of certificates of land ownership rights in Indonesia is the authority of the Land Registry Regency/City, for the prior issue certificates of land property rights shall be registered by the section of the Measurement and Land Registration (MLR) Land Agency.

Land registration to obtain a certificate of the overseas wear Torrens system is proving absolutely. According to Chambert Robert ${ }^{8}$ that the registration of land and issuance of certificates, obliges states to compensate landowners who are suffering or damage, falsification of signatures. Therefore the strength of the registration of land based on land surveys applicants who register their land. If there are claims that are reasonable should not be listed. Thus the land registration system used in Australia, New Zealand, Canada, Algeria, Tunisia, Congo, Spain, Norway, Fiji, Canada, Philippines, India and so on.

Thus, in Indonesia land registration system to obtain land certificates as evidence of a strong and a few countries in the world to obtain a land certificate as evidence that absolute.

Definition of Property Rights to Land

Article governing land, property rights Article 20-27 BAL. In Article 20 BAL affirms that:

\footnotetext{
${ }^{5}$ Jose Alice Dienet, 2010, Gassroots based agrarian reforn in Santa Cruz: A reason to hope for the end of land concentration, Master Programme Comflicts, Territotories and identities CICAM \& Human Geography, Radboud University Nijmegen, page 26.

${ }^{6}$ Ibid. 2008, page 63

${ }^{7}$ Efendi Perangin, 2007, Agrarian Law in Indonesia a Study of Legal Practitioners Viewpoint, CV Radjawali Jakrta, page 1

${ }^{8}$ Chamber Robert, 2001, page 445

DOI: $10.9790 / 0837-2110031422$

Www.iosrjournals.org 15 | Page
} 
1. Property rights are the right of hereditary strongest and most were able to possess the land by the provisions of Article 6

2. Property rights can be switched and transferred to another party.

To scrutinize to the foregoing article that hereditary defined property rights that can last for life can be owned but may be continued to the heirs if it dies. Strongest shows that property rights have a term of property rights has no time limits and rights registered in the Land Office had evidence of rights or the right base for the issuance of certificates. Fullest showed that property rights can be utilized for the rights to more land and became the parent of the land, such as ownership of land can be made into a lease right of use and building rights.

Thomas Aquino ${ }^{9}$ stated that private property is a natural right of humans. Also, it can be seen from the level of creation starts from the earth, animals, and plants and eventually humans. That stance led to the property rights belong to the absolute, Indonesia's property rights to land do not own the land, thus refers to Article 6 of the Basic Agrarian Law which stipulates that any land rights with social functions. This means that property rights to land when necessary in the public interest should be released for the mutual benefit of society.

\section{METHODOLOGY}

The method used is the socio-juridical research (socio-legal research). This study was conducted in Takalar Regency with the consideration, that in anticipation of the implementation of regional autonomy.

The study population was the whole community in Takalar Regency who have obtained a certificate for the land of his property at the Land Office as many as 2,250 people, with sampling techniques purposive for program services people land certificate is called a "Larasita" in the form of certificates of mass (CM) and conventional, with taking a sample of 75 respondents to the questionnaire charging rural communities and conducted interviews official in the Land Office of Takalar Regency. The type of data required in this study is a qualitative and quantitative data. The source of the data obtained in the form of primary data and secondary data. The data collection engineering used, observations, questionnaires, documentation and interviews.

\section{RESULTS AND DISCUSSION}

\section{Description of Implementation of Land Certification in Takalar Regency}

The implementation of land titling in Takalar Regency is experiencing mediocre and downs from year to year, it can be seen in table 1 .

Table 1. The number of requests for certification of land rights in Takalar Regency

\begin{tabular}{ccccc}
\hline No. & Year Application & $\begin{array}{c}\text { The LMPDP's } \\
\text { Applicant }\end{array}$ & $\begin{array}{c}\text { The Redis' } \\
\text { Applicant }\end{array}$ & Total \\
\hline 1 & 2011 & 3.000 & - & 3.000 \\
2 & 2012 & 3.000 & 1.000 & 4.000 \\
3 & 2013 & - & 1.250 & 1.250 \\
\hline & Total & 6.000 & 2.250 & 8.250 \\
\hline
\end{tabular}

Source: Data processed from the Land Office of Takalar Regency, 2014

From the data above shows that the applicant land passing through the World Bank Project "Project: Land Management and Policy Project" (LMPDP), which is managed by PT Bristha. This project began in the year 2011 to 2012 with the number of 9,000 plots of land property rights. In 2011 until 2012, for the Redis' applicant (ground self-government) does not exist, only in 2008 the numbers of the applicant 1,000 people and for the year 2013 as much 1,250 applicants, and all of them have completed their submission ${ }^{10}$.

The applicant for certification of property rights over land are greatly increased sharply due LMPDP Project of the World Bank, which started operation since 2011 with the number 9,000. Land field. Fees collected for the Project LMPDP quite cheaply just pick RP.75.000, - (seventy five thousand rupiah) and stamp duty for RP.6.000, - x 3 pieces $=$ Rp.18.000, -, so the total number of all cost RP. 93,000, - compared to the usual certificate application fee (Redis) around Rp.3.000.000, - (three million) costs about 25 times the cost ${ }^{11}$.

With the cost of the World Bank through the Project of LMPDP is very supporting the implementation of land certification in Takalar Regency so the certification of land ownership rights drastically increased about $300 \%$. This shows that the World Bank's program in terms of certification of property rights to land in Takalar Regency is very helpful for people.

\footnotetext{
${ }^{9}$ S R Nur, 1995, Agrarian Law I, Publisher Graduate of Hasanuddin University, page 13

${ }^{10}$ Interviews, Lukman as Head of Sub Division of Education District Land Registry, February $3{ }^{\text {rd }}, 2014$.

${ }^{11}$ Interviews, Mantasia, Head of Adminstration Takalar Land Agency, February $5^{\text {th }}, 2014$.

DOI: $10.9790 / 0837-2110031422 \quad$ www.iosrjournals.org $\quad 16 \mid$ Page
}


The purpose of the World Bank provides assistance to certification of land in Takalar Regency is to provide legal certainty for the people in managing and own the land. Therefore, the land that is certified will give a sense of security and peace for the people in the management of property rights to land. They did not think to mention that in the future there will be mutual accountability sued because they already have legal certainty. The legal certainty of the government of the Republic of Indonesia would give legal status and legally enforceable for the title for the land, so that people who have been certified property rights over the land will be protected by applicable law.

\section{Legal Compliance Level Communities to the certification of the Land}

The law of the land is very important for people to be obeyed, in order to avoid the crux of the rights over the land. Therefore the need of law enforcement as well as possible so that the law can be authoritative legal means, how it can be used as a commander not as a means of political and business tools for political actors and businesses, so that the law be obeyed and respected by the community.

Andi Zainal Abidin Farid ${ }^{[12]}$ cites the opinion of Lapagala Grandma Mallomo in Sidrap Regency in the sixteenth century that the law is adek-e temmakkeanak temmake eppo, meaning that the law was not familiar with a child or grandchild, therefore the law should be enforced in a society without viewing the reed. Because the law has to be upheld, then to measure how the public reaction to the rules that have been defined whether accepted or not, in other words whether the rules were obeyed or not.

To measure whether or not adhered to the land law in Takalar then it can be seen in Table 2.

Table 2. Basic Rights Obtained for The Land Property Rights

\begin{tabular}{clcc}
\hline No. & \multicolumn{1}{c}{ Category Answer } & Frequency & Percent \\
\hline 1 & Legacy & 25 & 33,33 \\
2 & Sale and Purchase & 34 & 45,33 \\
3 & The determination of the Government & 5 & 6,66 \\
4 & Grants will & 11 & 14,66 \\
\hline \multicolumn{4}{r}{ Total } \\
\hline
\end{tabular}

Sources: Data processed and questionnaire B No. 1, 2014

From the data above shows that $25(33.33 \%)$ of respondents admitted that the land property rights acquired are lining rights of the estate, $34(45.33 \%)$ of respondents admitted that the land property rights acquired are lining their rights of land results purchase of land, $5(6.66 \%)$ of respondents admitted that the land acquired property rights of the land are lining determination of the government, and $11(14.66 \%)$ of respondents admitted that the land property rights acquired are lining their rights of land grants and will.

Thus the more people acquire land, property rights with the base of the results of the sale and purchase of land and heritage, while this government and grant-will is still lacking. This proves that the land rights of long transferred to another person, therefore opening new land in the form of the determination of the government are lacking, meaning the land that is in Takalar more diverted from the land of old rights (the previous owner) to land rights The new (the new owners).

Proving land for long been a land rights new rights will be regulated in Article 24 paragraph (1) Regulation No. 24 of 1997 that ........, Land rights derived from the conversion of old rights evidenced by the evidence of the existence of those rights in the form of written evidence, witness statements or statements concerned that the levels of accuracy by the Committee Adjudication in land registration systematically or by the Head Office land in sporadic land registration, are considered sufficient to register rights, rights holders and the rights of others burdens.

In the exercise of the right long transition to a new right of a land is the primary duty and authority of the Land Deed Official (LDO). The key task of LDO of carrying out partial registration of land with a deed as proof that he has done as a legal affairs binding to the agents, so that it has binding legal force in the form of the deed as a deed of sale, deed of inheritance, deed of grant-wills and so on. The birth of the new certificate is the right base to holders of property rights to land.

This basic set in Article 6 paragraph (2) of Government Regulation No. 24 of 1997. The base of rights is acquired by the land owners will be reinforced with a deed of ownership of land by via the Land Deed Official (LDO) District and Deed Official Land raised by the Ministry of Justice and human rights.

${ }^{12}$ Andi Zainal Abidin Farid, comparison-Principle of Criminal Customary Law Principle of Criminal Law Indonesia with Indonesia with the Principle of Criminal Justice and Texas Western Europe. Publisher UMITOHA Makassar, pages 20-57, 1997 
Land Deed Official (LDO) sub-district which meant that at the time did the deed. So the deed is issued as the district head offices and their jurisdiction, so they had to look for evidence of juridical by searching through the history of the land on subordinate levels that the urban/rural. Evidence obtained by the district can then be processed deed to be made. LDO appointed by the Ministry of Justice and Human Rights is an agency that has the authority designated by the central government in carrying out its duties by a deed of land in the area. The deed must necessarily be based on evidence by finding the juridical history of land which is usually obtained through the Village.

In the event of transfer of the property for sale and purchase, donation and community will then finish through the Land Deed Official or notary; it can be seen in table 3.

Table 3. The Society Makes an Authentic Through LDO/Notary

\begin{tabular}{clcc}
\hline No. & \multicolumn{1}{c}{ Category Answer } & Frequency & Percent \\
\hline 1 & Always did the deed & 27 & 36 \\
2 & Sometimes did the deed & 23 & 30,67 \\
3 & Rarely did the deed & 14 & 18,67 \\
4 & Not did the deed & 11 & 14,66 \\
\hline \multicolumn{5}{c}{ Total } & 75 & \\
\hline
\end{tabular}

Sources: Data processed from questionnaires B No. 2, 2014

From the data above shows that $27(36 \%)$ of respondents stated that the deed is always, made through the Land Deed Officer/Notary in case of alienation of land, $23(30.67 \%)$ of respondents said that sometimes made through LDO deed/Notary in case of alienation of land, $14(18.67 \%)$ of respondents stated that rarely made through LDO deed/Notary in case of alienation of land and $11(14.66 \%)$ of respondents stated that it is not made if there is a transfer deed land rights.

Thus the people who transferred the land his property in the form of buying and selling land, property rights they will take advantage of the Land Deed Official (LDO) as an institution for the maintenance of transfer of rights in Indonesia. This LDO there are handled by the district which is called LDO the District there are also appointed by the Minister of Law and Human Rights, all of which can be transferred land ownership rights legal status of buying and selling land.

Notaries can accept the transfer of land ownership rights and legal status of property rights on land transferred for grants, wills and inheritance to issue authenticity certificates. May also for people who are Muslims who wish to divert and land switch his property through via the local Religious Courts (Religious Court District/City) for the authenticity of such certificates issued inheritance deed, grant deed and the deed will. Religious Courts indeed are an authority in its territory in a regency/city.

The diversion is intended that the transfer of property rights to land because of the element of intent, such as grants, wills, purchase, or exchange. Switching is intended that the transfer of property rights to land because of the element of transfer of rights automatically because of the owner of the land, property rights dies; the legal status is transferred to heirs automatically.

Their management to make the land deed of property rights in the event of transfer of rights shows the community has a high compliance with the law to seek legal certainty. Communities know that with their certificates of land ownership rights owned by the government is to give peace to manage their land because they are convinced that the certificate of title for the land manage the land more secure, so if its status as farmers, traders, clerks and so they are no longer there are fears later to occur of land conflict in the future.

Table 4. A response regarding community certification of land property rights

\begin{tabular}{clccc}
\hline No. & Category Answer & Frequency & Percent \\
\hline 1 & Very agree & 14 & 18,66 \\
2 & Agree & 50 & 66,66 \\
3 & Less agree & 7 & 9,33 \\
4 & Disagree & & 4 & 5,33 \\
\hline & Total & 75 & 100 \\
\hline
\end{tabular}

Sources: Data processed from questionnaires No. B 3, 2014

From the data above shows that $14(18.66 \%)$ of respondents stated that the certification of land property rights are made in mass certification and conventional strongly agree, 50 (66.66\%) of respondents stated that the certification of land property rights conducted mass certification and conventional agreed, 7 $(9.33 \%)$ of respondents stated that the certification of land property rights are conducted in mass and 
conventional disagree, and $4(5.33 \%)$ of respondents stated that the certification of land property rights are made mass certification and conventional disagree.

Thus, more people agree that if carried out land titling property rights conducted both mass certification (MC) and conventional. This proves that people are always looking for evidence of those who have land ownership rights with evidence of strong recognition of the state (government), therefore the community is very aware that the certificate is very beneficial for them to seek legal certainty is strong. Therefore, people are very adherent to one of the aims of the law is legal certainty. The reason is that with adherence to the rule of law will be more peaceful in managing the property rights over the land so that both housing, land, wetland (paddy), dry land (plantations) and so on. They feel more secure working and the land more productive in its utilization. Good land use is an objective law that the purpose of the law is justice, legal certainty and benefits can be realized. The certification of property rights to land has a legal purpose, namely the rule of law means in the presence of a certificate of land owned by a person means they have strong evidence, as adopted by the Indonesian state system of land registration negative with a positive tendency. This means that no rights are unobjectionable that determine whether it is a right and a transfer is rightful legal act performed is not registered. Although people know the benefits of the certificate of property rights over land still need to be revealed that the factors that encourage them to want to obtain a certificate of ownership of land, this varies answers to society as they obtain a certificate for the land by a factor of self-awareness, lack of legal certainty, is used to manage credit in the Bank or used as evidence in a land dispute, this hat can be seen in table 5 .

Table 5. The cause of encouraging people to have land certificates

\begin{tabular}{clcc}
\hline No. & Category Answer & Frequency & Percent \\
\hline 1 & Self-awareness & 26 & 34,67 \\
2 & For legal certainty & 37 & 49,33 \\
3 & To obtain credit in the Bank & 10 & 13,33 \\
4 & Because there is a dispute to be used as evidence & 2 & 2,67 \\
\hline \multicolumn{2}{r}{ Total } & 75 & 100 \\
\hline
\end{tabular}

Sources: Data processed from questionnaires No. B 4, 2014

From the data above shows the $26(34.67 \%)$ of respondents stated that prompted them to have a certificate of land ownership rights is self-awareness, 37 (49.33\%) of respondents stated that the push to have a certificate of land ownership rights are for legal certainty, $10(13.33 \%)$ of respondents stated that to obtain bank loans, and $2(2.67 \%)$ of respondents stated that since there is no dispute that serve as strong evidence.

Thus, in general the factors that encourage people to obtain a certificate for the land of his property is self conscious and seek legal certainty so that it has the force of law is as strong evidence while encouraging people who claim used to obtain credit and serve as strong evidence in the case of the land disputes, few are stating so. Therefore, the level of legal compliance community in the certification of land is very great significance for the community because it is used as a means of strong evidence.

Strong evidence in question is the land has been issued a certificate from the Land Agency, and there were sued by reason of any evidence obtained as a formal legal basis as a means to sue then they can pursue a lawsuit in the District Court. Although no formal evidence found after quite 5 years since the issuance of the certificate of no objection or a lawsuit filed in the District Court, the already strong legal force means no longer allowed to land ownership certificate carried lawsuit.

This is regulated in Article 32 paragraph (2) Regulation No. 24 of 1997 that a plot has been legally issued certificates on behalf of the person or legal entity ....... if within 5 years since the issuance of the certificate is not filed an objection in writing to the certificate holder and the Head of the relevant land Office or file a lawsuit in court over control of the land or the issuance of the certificate.

The legal basis showed a lawsuit will be rejected by the District Court if the certificates have been issued 5 years and no one sued, meaning the land of the certificate holder has legal force and effect certainly strong. Here we see that the national land law in Indonesia is adopting a negative tendency positive system.

Basic land certificate applies strong and not absolute, but it is stipulated in the Basic Agrarian Law as a national agrarian law in Indonesia is emphasized in Article 6 of Law No. 5 of 1960 that all of the social function of land rights. This means that when the land was needed for public purposes, it should be released, land not personally attached to its owner (valid absolute). Therefore, the land ownership in Indonesia can be released back if necessary for the public interest was the philosophy of Indonesian land in the public interest takes precedence over the personal or group interests are essentially derived from the philosophy of Pancasila as the state ideology. 


\section{Socioeconomic influence of the certificate of Property Rights to Land}

According Manangkasi to determine how much influence the variable socioeconomic factors to the certification of property rights over land, whether weak or strong it can be used statistical test and the chi-square test followed by contingency ${ }^{13}$

\section{1) The level of the certification fee Property Rights to Land}

The cost of certificates of land ownership rights will affect the certification of land, to prove it can be done chi-square test. Chi-square test results showed that the values obtained $\mathrm{X}^{2}$ count $=12.43$ and $\mathrm{X}^{2} \mathrm{tab}=$ for a significance level of $5 \%=16.919$ on the degrees of freedom 9. So the chi-square value obtained from the processing of data is smaller than the value of chi-square the theoretical significance level of $5 \%$. The test results indicate contingency $\mathrm{CTF}=43.53$ and $\mathrm{KKM}=0.866$, which means the relationship $43.31 \%$. Figures $43.31 \%$ indicates that the relationship is weak.

The analysis of these results, showing that the cost land certification property rights affect the least expensive rate of the certification cost of land property rights, meaning that the cost factor greatly influencing the community to certificate land, although judging by the closeness of the relationship is still considered weak. The issue of cost as a reason for the certification of land is not too strong influence. The existence of such cases due to the average community obtain a certificate for their land through mass certification (MC) financed by the World Bank through the "Land Management and Policy Project" (LMPDP), which is managed by PT Bristha.

With the LMPDP, the cost of certificate of land certification property rights, do not experience, because these costs are subsidized by the World Bank. Therefore, the results of subsidies, especially the World Bank certificates of land in Indonesia provide a very positive influence on peace and security by the holder of title for the land.

\section{2) The level of certification of the Income Effect of Property Rights to Land}

The income level average income of respondents was varied in number, namely from <RP. 2.000.000, up to > RP. 6.000.000,- upwards. Income varying influence on the certification of land ownership rights. To find out how much influence the level of income of the certification of land property rights can be seen in the results of this statistical test taken.

Chi-square test results showed that the values obtained $X^{2}$ count $=10.56=$ and $X^{2}$ tab $=$ for a significance level of $5 \%=16.919$ on the degrees of freedom 9. So the chi-square value obtained from the processing of data is smaller than the value of the chi theoretically square with a significance level of 5\%. The test results of contingency indicate the $\mathrm{KKM}=0.351$ and $\mathrm{KKM}=0.866$, which means the relationship $40.53 \%$. Figures $40.53 \%$ indicates that the relationship is weak.

The analysis of these results shows that the average income of people is influenced by the level of certificate land, property rights: that means the average income factor affects the level of society is a certification of land ownership rights, although judging by the closeness of the relationship is still considered weak. So the public income effect is weak against the certification of land ownership rights. It is possible for them LMPDP projects financed by the World Bank that it enables people do not think of the cost of land titling problems, since the project is only allowed to charge as much as Rp.75.000 stakes, - (seventy five thousand rupiahs) and stamp duty 3 pieces as much as RP. 18.000, - (eighteen thousand rupiahs), so the total overall cost only about Rp.83.000, - (eighty three thousand rupiahs). These costs are minimal compared with conventional certification that the amount of approximately RP.3.000.000, - (three million rupiahs).

1) Income eligibility levels to meet the needs influential In certification against property rights over land

Feasibility level of respondents' income is varied, the recognition of the community is saying very much on the level of need, and there are also those who say do not meet the level of need to know how much influence the feasibility of community income to make ends meet against the certification of land property rights can be seen in the results of statistical tests below this.

Chi-square test results showed that the values obtained $X^{2}$ count $=4.69$ and $X^{2}$ tab $=$ for significance level of $5 \%=16.919$ on the degrees of freedom 9. So the chi-square value obtained from the processing of data is smaller than the value of chi-square the theoretical significance level of $5 \%$. The test results indicate contingency of $\mathrm{KKP}=0.242$ and $\mathrm{KKM}=0.866$, which means the relationship $28.01 \%$. Figures $28.01 \%$ indicates that the relationship is weak.

The analysis of the results demonstrates that the feasibility level of income to meet the needs of the community is the effect on the rate certification of land property rights, meaning that eligibility factors of income to meet the needs of the community is the effect on the rate certification of land ownership rights,

\footnotetext{
${ }^{13}$ Manangkasi, 1995, Publisher Graduate Program of Hasanuddin University, page 75

DOI: 10.9790/0837-2110031422 www.iosrjournals.org $\quad 20 \mid$ Page
}


although judging by the closeness of the relationship is still considered weak. So even if people's income is less feasible to meet the needs of their families still obtain a certificate for the land.

The existence of such a case is caused due to subsidies from the World Bank so that the certification cost of land property rights less costly. It is very cheap, so generally people who have land of property rights motivated to obtain a certificate of property rights over the land.

\section{4) The level of certification of the Impact of Work Status Property Rights to Land}

As explained that the people's livelihood is very varied, there is status as civil servants, merchants, farmers, fishermen and so on. Therefore, to determine how much influence the status of the community work towards the certification of land can see the results of this statistical test taken.

Chi-square test results showed that the values obtained $X^{2}$ count $=16.56$ and $X^{2}$ tab $=$ for a significance level of $5 \%=16.919$ on the degrees of freedom 9 . So the chi-square value obtained from the processing of data is smaller than the value of chi-square the theoretical significance level of $5 \%$. The test results indicate contingency and $\mathrm{KKP}=0.425$ and $\mathrm{KKM}=0.866$, which means the relationship $49.127 \%$. Figures $49.127 \%$ indicates the relationship is weak.

The analysis of these results, indicating that the level of employment is the effect on the rate certification of land property rights, meaning factors affects the level of employment is a certification of land ownership rights, although judging by the closeness of the relationship is still considered weak. So the influence of community work to obtain a certificate for the land is still relatively weak.

Although the level of work less to certification of property rights to land, but with the certification of land property rights for workers whose profession as a farmer was more at ease working in the manage of agriculture land or plantation land. So as businesses such as wholesalers and entrepreneurs will utilize land ownership certificate to make a guarantee in the Bank in increasing their capital. Therein lies the role of land certification will provide additional investment in managing its business.

\section{Conclusions:}

\section{CONCLUSION AND RECCOMMENDATIONS}

1. Compliance with the laws of society towards the certification of land property rights in Takalar Regency still classified as moderate (not high and not low). Therefore, some people there who obtain a certificate for the land in case of transition of property rights, there is a direct care of a certificate as soon as possible, some have not, there is also only limited rights only maintenance board in the form of a deed of sale, deed of grant, deed of inheritance and so on, which is important to have a juridical evidence.

2. Social and economic factors such as income, eligibility for the family, education, employment status, giving the effect of the weak against certification of land property rights. This is because people always expect help from the government's subsidized by the government, is also ever undertaken by the World Bank assistance through the Land Management and Policy Project (LMPDP), help people in certifying property rights over the land.

\section{Recommendations:}

1. The certification of land mass (LM) is very motivating people need to be increased role in society with an approach through international institutions like the World Bank.

2. Assessment of the public costs of conventional certification considered expensive because it is expected the authorities how to reduce the cost so that people can reach them.

\section{REFFERENCES}

[1] Boedi Harsono, 2008, History of the Formation of the Basic Agrarian Law Contents and Implementation, Publisher Jambatan Jakarta.

[2] Yudha Pandu, 2010. The Association Regulation Legislation Rights to Land, Indonesia, Publisher Legal Center Publishing.

[3] Google, www//http//wwn Surakarta, Adimin, January 8, 2008

[4] Jose Alice Dienet, 2010. Grassroots based agrarian reform in Santa Cruz: A reason to hope for the end of land concentration, Master Program Conflicts, Territotories and identities CICAM \& Human Geography, Radboud University Nijmegen.

[5] Effendi Perangin, 1997. The Agrarian Law in Indonesia a Study of Legal Practitioner Perspective, Publisher CV Radjawali Jakarta.

[6] Chambers, Robert, 2001. An Introduction to Property Law in Australia, (Australia: LBC Information Sevice) 
[7] S R Nur, 1995. Agrarian Law I, Publisher Graduate Program of Hasanuddin University

[8] Andi Zainal Abidin Farid, 1997. The Comparison of Common Law Principles of Criminal Indonesia with the Principle of Criminal Law and Texas, Publisher UMITOHA

[9] Manangkasi, 1995, The Social Statistic Moduls, Publisher Graduate Program of Hasanuddin University. 